\title{
HORTICULTURE IN VRIKSHAYURVEDA
}

\author{
M.V. Praphulla*
}

Vrikshayurveda is one of the ancient Botany texts, in Sanskrit language, written by Surapala. The title vrikshayurveda means "science of plant life". It deals with 170 species of plants' health and productivity. Surapala has included plants bearing fruits, flowers, and shade giving. His main intention in writing the vrikshayurveda is to ensure that conservation of plant diversity of selected species. It is along with the people's beliefs; religious attitudes, superstitions and folk knowledge are well represented. The benefits for people by planting trees associated with religious merits, plant-man-god relationship is emphasized. This belief is continued even today in our country. Surapala suggests पुरुषार्थः धर्म अर्थ काम मोक्ष can be achieved through planting plants and trees of various species. 'The holistic development of society and intergenerational equity, role of plants are highlighted. These are key words even today for the sustainable development of agriculture.

Surapala has taken references from several ancient texts like Atharva Veda, Brhatsamhita of Varahamihira, Sragadhara paddathi of Sragadhara, dealing with agricultural and botanical aspects. The medicinal aspects of Charaka and Susruta Samhitas, economical and socio religious aspects from Grhysutras, manusmruthi, Arthashastra, Puranas and Mahabhartha and others. But he has concentrated on soil, plant propagation, methods planting, nourishment, diseases, treatment, and horticultural wonders. A few aspects of these topics as sample are described in brief in this paper.

Prof. of Sanskrit, Dept. of Languages, Christ College Bangalore 
Soil: The soil is basic factor for growing plants and trees. The suitable soil is the one rich with minerals and salts. The Surapala has classified soil basically into three types. They are Arid, Marshy, and Ordinary. Soil based on colour and taste is further divided into six types. The colours are Black, White, Pale, Dark, Red, Yellow and savor, sweet, sour, salty, pungent, bitter and astringent. Further he has given brief explanation of best suitable land for garden as a soft soil, with white or yellow or red coloured. It should have accessibility to water resources and even, surrounded by trees. The ordinary soil is good for all types of plants and trees. ${ }^{3}$ At the same time the lands unsuitable for growing plants are arid, marshy, poisonous elements present, stony, and lack of water resources.

Plant Propagation: The plant propagation or growing new plants through sowing of seeds, grafting and transplanting the seedlings are explained. Basically the plants are classified as vanaspati, trees bearing fruits without flowers, drumas are trees bearing flowers and fruits, Lata are creepers with tendrils and Gulmas are the trees with short and bearing branches. ${ }^{4}$ Normally plants are propagated through planting seeds or stalk or bulb.

The desired tree or plants seeds for planting are extracted from dried fruits in natural course and season. The trees or plants in selected seasons only the seeds suitable for planting can be collected. If it is from same plant but during different season the growth of plant or yield may not be rich and good therefore Surapala has laid a rule to collect during a suitable season. Then the seeds thus collected are sprinkled with milk and dried in shade. They are further smoked with mustered seeds mixed with bidanga. It can be rolled in powder of brhati, tila and nala, for bringing excellent condition for sowing. This is a general method adopted in general for many common varieties. Then after offering prayers to Vastu devatha, thus processed seeds are sowed in soil by owner of the land. Later the servants continue to sow the rest of the seeds. The seeds sowed are covered with grass, and sprinkled with milk mixed with water. After seeds have sprouted, water should be sprinkled and cover of grass is removed. The soil should be allowed to dry.

Method of planting: Seedlings are planted in even ground, where sesame or black gram is not grown earlier or where heaps of mud strewn over the heaps of flowers of sesame.

\section{चतुर्ह नूाषोडनूार्विनूब्विनूतिहत्सैस्सदंतलानि । क्रमशो निदितप्रध्मवरमिति तरूसंपदेनियतं ॥}

The distance between the two plants, are to be 14 or 16 or 20 forearm lengths. With this particular distance results in inferior, mediocre and excellent yield of the trees respectively. Distance between two bushes should be 4 or 5 forearms lengths. 
If distance is more the strong winds cause danger for their existence. If the plants are closer production of fruits or flowers will be affected. So distance should be strictly maintained.

The preparation of soil in the form of pits is also explained for the rich yield. Even at present this method is followed for growing plants and trees. The pits for planting seedlings should be prepared well in advance. The length, breath, and depth of pit should be a forearm measure uniformly. They should be dried, filled with cow bones, cow dung and burnt. Ashes are removed after natural cooling and Kunapa water [liquid manure] should be sprinkled. The pits are filled with good mud. The vegetables are sown along with other seeds or seedlings. The large seeds are sown single and small seeds in multiples.

The plants and trees grown through the grafting a branch are normally done in case of seedless trees. The stalk selected should be having eighteen angulas in length. It should not be either too tender or too hard. Half of the stalk should be smeared with plenty of cow dung. The three fourth part of the stalk should be planted inside the pit. Then sprinkled with water mixed with soft sandy mud.

The bulb should be planted in pits of one arm length, breadth and depth, filled with mud mixed with thick sand. Small plants should be planted or transplanted during daytime, when they are one forearm length. The roots are smeared with honey, lotus-fiber, ghee and bidanga. The big trees transplanted roots covered with mud during evening. The direction for planting different specious should be followed for prosperity of people.

Nurturing: Nurturing through additional nurturing materials is common. At present people use artificial manures for growth and yields. But Surapala has provided a natural manure kunapa. Kunapo is the liquid manure, prepared by mixture of excreta, marrow of the bones, flesh, brain, blood of boar and water. It is stored underground. The mixture is boiled with water and stored in oiled pots. It is added with sufficient quantity of husk. Later on roasted in iron pot, added with sesame oil cake and honey, soaked black gram and little ghee is added. The measurements for these ingredients are at random, as Surapala has not mentioned the exact measurements in his work. In rainy season and autumn or when soil becomes dry, juice of medicinal plants mixed with urine, marrow and milk should be given. The other types of nourishments for different species like grape creepers with excreta of cock, water and fish fat: for date palm, betel nut, kataka, decoction of flesh of cow, hog and gangetic porpoise with water. Manure of saphari fish mixed with sesame is also added. In this manner several varieties of trees and plants are nurtured with different types of nourishments are explained in 64 stanzas. 
Watering: Newly planted in arid region should be watered every morning and evening, for 15 days, till soil is fully soaked. In marshy land water should be restricted to only once in five days. In ordinary soil water should be done for ten days every morning and evening, the quantity being limited. Well rooted plants, are watered alternate day in winter, every evening in spring, and thrice a day in summer. This process is still followed normally in India.

Ailments: In 18 stanzas the description of common ailments related to trees and plants are described. The disease or ailments are classified as internal and external. The internal ailments are caused by the imbalance caused in three major factors; they are vata, pitta and kafa.

The vata is due to the land becoming arid on account of excessive supply of dry and pungent matters. These diseases are: thinness and crookedness of trunk, appearance of knots on the trunk and leaves and the fruits being hard, with less juice and sweetness.

The diseases of the kafo type occur only during winter and spring. If the trees are watered excessively, containing materials of sweet, oily, sour or cold the kafa type diseases occur. These diseases are taking long time to bear fruits, paleness, dwarfing of leaves, and tasteless and premature fruition of fruits. The trees ooze out even without wounds.

The pitta type of diseases occur at the end of summer, if the clouds disappear and the trees are excessively watered with materials which are bitter, sour, and strong. The pitta type of diseases are, yellowness of leaves, untimely dropping of fruits, dryness, paleness of leaves, flower and fruits, and decay.

Other than these types even if exposed to scorching heat of the sun the roots are eaten away by insects causing, dryness and yellow colour or excessive paleness. Excessive stormy winds cause stress and causes breaking of branches, uprooting, and twisting of trees. The fire, wind, friction with other trees, constant existence of shade, inhibition of too many birds, excessive growth of creepers and weeds nearby will also destroy trees.

Treatment: The various methods for curing diseases caused in plants and trees are listed with an intention to maintain balance of the three datus. The normal medical treatment given for growing, are also used for treatment. The diseases caused by vata can be cured by sprinkling of kunapa water. It can be quickly cured by mixture of fat of the hog, oil of the gangetic porpoise, ghee, hemp, hair of horses and cows horn boiled and set to a decoction. 
The kafa type of diseases is cured by sprinkling decoction of roots of sriphala, sarvatobhadra, patala, ganikarika, and syonaka, along with scented waters. The paste of white mustered feed to roots. The water mixed with sesame and ash is also given.

The pitta type treated with milk, honey, yastimadhu and madhuka, in the form of decoction. Other than these specific treatments are also given for different diseases.

Horticultural wonders: The different wonders in growing trees and plants had fascinated our ancients. Surapala has elaborately explains the wonders in about 70 stanzas. They had even tried different methods for better fruits and flowers. A few samples are given here.

The milk of she-goat showered producing flowers throughout the year. Bakula tree flowering with champaka flowers, when flesh water is given after filling mud with kalaaya and python skin. In the same manner various reasons for destruction of tree are also given. The coconut trees dies due to water used for cleaning rice is given. Neem leaves water kills cotton tree.

The importance of trees and plants: Planting the trees or plants are not only important for maintaining purity of air and aesthetic beauty of the place. The various merits are not limited to human world, even extended to other worlds. The five trees planted are considered to offer libation to planter through offering leaves, flowers and fruits. Therefore Surapala explains thus

दशकृपसमावापीदशवापीसमोहृद्दः । दशहद्दासमः पुत्रोदशपुत्रसमोद्रमुः ॥

The planting considered for achieving the dharma, artha, kama and moksha.

The planting of some of the religious importance oriented trees is providing permanent benefits for man are thus;

The tulasi giving benefit of a place to stay in heaven. The planter of bilva possess the permanent wealth useful for many generations. The Asvitha tree planter benefited by a place in Hari's abode. Dhatri is benefited with gifting of earth, sacrificial fruit, and placed as celebrate. The planter of banyan will get place in shivaloka.

Surapala has also provided the merits and demerits for planting certain variety of trees in and around the house. He has also provided the direction to plant the important religious trees in gardens or in house. 
Nyagrodha planted in east, udumbara to south, and plaksa to north and pippala to west to yield wishes of planter. These are considered as auspicious trees. The restriction to avoid planting or allowing even naturally growing the following trees in these directions; they are asvattha to east, plaksa to south, udumbara to north and nyagrodha to west.

Other than these prescriptions Surapala has general instruction to have happiness in the family by avoiding shadow of any tree on the house. The garden not to be in south or southwest, or northeast side of the house. Therefore it should only be on west, north or east of the house for prosperity. Sages who had contributed to horticulture in ancient times might have laid down these rules. Which might have been present during Surapala time, as in Bruhatsamhita of Varahamihira has names of Parashra and other sages' names in relation to certain aspects of Botany. As Surapala himself mention in his text that he has edited the text on horticulture. The other text might have been lost in course of time, due to several reasons. Definitely the horticulture was one of the best branches of knowledge used for the purpose of health, wealth and prosperity in this world and even after death. Therefore it is not recent innovation of people of modern period.

\section{References}

1. Surapala Vrikshayurveda edited by Agri-historical bulletin no.l. Asian agri-historical foundation.

2. M. Ramakrishna Bhat edited Burhła Samhitha of Varahamihira, part-l. 